\title{
DURABILITY OF ALUMINA SILICATE CONCRETE BASED ON SLAG/FLY-ASH BLENDS AGAINST ACID AND CHLORIDE ENVIRONMENTS
}

\author{
ZDRŽLJIVOST BETONA NA OSNOVI GLINICE IN SILIKATOV IZ \\ MEŠANICE ŽLINDRA/LETEČI PEPEL NA KISLO IN KLORIDNO \\ OKOLJE
}

\author{
Rajagopalan Gopalakrishnan ${ }^{1}$, Komarasamy Chinnaraju ${ }^{2}$ \\ ${ }^{1}$ Sri Venkateswara College of Engineering, Department of Civil Engineering, 602117 Sriperumbudur, India \\ ${ }^{2}$ Anna University, Division of Civil and Structural Engineering, 600025 Chennai, India \\ gopalakrishnan@svce.ac.in, rajagopalan.gopalakrishnan0@gmail.com
}

Prejem rokopisa - received: 2015-07-19; sprejem za objavo - accepted for publication: 2015-12-02

doi:10.17222/mit.2015.230

\begin{abstract}
The durability of a concrete mainly depends on its resistance against acid and chloride environments. This article presents an investigation of the durability of geopolymer concrete with GBFS (Granulated Blast Furnace slag), Fly ash (class F) and alkaline activators when exposed to $5 \%$ sulphuric acid and chloride solutions. GBFS was replaced by fly ash with different replacement levels from $0 \%$ to $50 \%$ in a constant concentration of $12-\mathrm{M}$ alkaline activator solution. The main parameters of this study are the evaluation of the change in weight, strength and microstructural changes. The degradation was studied using Scanning Electron Microscopy (SEM) with EDAX. From the test results it is observed that the strength of the geopolymer concrete with GBFS in ambient curing performs compared well to geopolymer concrete with GBFS blended with fly ash. The acid resistance in terms of the rate of reduction of strength of GPC with GBFS is $85 \%$, while for $40 \%$ replacement of fly ash to GBFS performs well with a reduction of only $53 \%$. Similar observations are also observed in a chloride environment in which $40 \%$ replacement of fly ash to GBFS performs well when compared to GPC with GBFS. Hence, geopolymer concrete with 40 $\%$ replacement of fly ash for GBFS is the appropriate level of replacement, satisfying the above durability properties.

Keywords: durability, geopolymer concrete, acid and chloride environment
\end{abstract}

Zdržljivost betona je predvsem odvisna od odpornosti na kislo in kloridno okolje. Članek predstavlja preiskavo zdržljivosti geopolimernega betona z GBFS (granulirana žlindra iz plavža), letečega pepela (razred F) in alkalnih aktivatorjev med izpostavitvijo $5 \%$ žvepleni kislini in kloridnim raztopinam. V GBFS je bila dodana različna količina: od $0 \%$ do $50 \%$ letečega pepela pri konstantni koncentraciji $12 \mathrm{M}$ raztopine alkalnega aktivatorja. Glavni parametri v študiji so bili sprememba teže, trdnost in mikrostrukturne spremembe. Degradacija je bila preučevana z uporabo vrstičnega elektronskega mikroskopa (SEM) z EDAX. Iz rezultatov preizkusov je opaziti, da je pri izpostavitvi trdnost geopolimernega betona z GBFS dobra, v primerjavi $\mathrm{z}$ geopolimernim betonom z GBFS s primešanim letečim pepelom. Odpornost na kislino, izraženo s hitrostjo zmanjševanja trdnosti GPC z GBFS je $85 \%$, medtem ko se pri $40 \%$ nadomestitvi letečega pepela v GBFS, ta ponaša dobro, s samo $53 \%$ zmanjšanjem trdnosti. Podobna opažanja so bila tudi v kloridnem okolju, v katerem se $40 \%$ nadomestilo letečega pepela v GBFS obnaša dobro, v primerjavi z GPC, ki vsebuje tudi GBFS. Torej je geopolimerni beton, s $40 \%$ nadomestitvijo letečega pepela z GBFS, primeren za zgoraj omenjeno zdržljivost.

Ključne besede: zdržljivost, geopolimerni beton, kislo in kloridno okolje

\section{INTRODUCTION}

The durability of concrete structures, especially those built in corrosive environments, starts to deteriorate after 20 to 30 years, even though they have been designed for more than 50 years of service life. Although the use of Portland cement is unavoidable in the foreseeable future, many efforts are being made to reduce the use of Portland cement in concrete. ${ }^{1}$ Inorganic polymer concretes, or geopolymers have been emerging as novel engineering materials with the potential to form a alternative element for the construction industry. ${ }^{2-4}$ Geopolymers show substantially superior resistance to fire ${ }^{5}$ and acid attack $^{6}$ and much less shrinkage than OPC Concrete. The tensile strength of geopolymer concrete falls within the range observed for OPC-based concrete. Also, the flexural strengths are generally higher than the standard model line for OPC-based concrete. This favourable behaviour can be attributed to the type of matrix formation in the geopolymer concrete. ${ }^{7}$ It has been reported that the stress strain relationship of fly-ash-based geopolymer concrete is almost similar to that of ordinary portland cement concrete. ${ }^{1}$ These advantages make the geopolymer concrete a strong alternative for replacing ordinary Portland cement concrete.

Geopolymers are produced by a polymerization reaction of strong alkali liquids such as sodium hydroxide $(\mathrm{NaOH})$, potassium hydroxide $(\mathrm{KOH})$, sodium silicate and potassium silicate with a source material of geological origin or by a product material such as fly ash, GBFS, metakaolin. The mixture can be cured at room temperature or heat cured. Under a strong alkali solution, an alumina silicate material dissolves and forms $\mathrm{SiO}_{4}$ and $\mathrm{AlO}_{4}$ tetrahydral units. 
Three common types of geopolymer are the polysialate $\mathrm{Al}-\mathrm{O}-\mathrm{Si}$ chain, polysialate siloxo $\mathrm{Al}-\mathrm{O}-\mathrm{Si}-\mathrm{Si}$ chain and polysialate disiloxo Al-O-Si-Si-Si chain. ${ }^{8,9}$ The raw materials commonly used for preparing geopolymers are clay and metakaolin. Studies are under progress recently are using the waste and byproducts for geopolymerization from waste materials. ${ }^{10-18}$ A number of research publications related to geopolymers have been published, with some reports on chemical composition or reaction processes, others relating to mechanical properties and durability. The compressive strength depends on both the $\mathrm{Si} / \mathrm{Al}$ ratio and the type of raw materials used. ${ }^{19-22}$ To improve the performance of these binders, a number of recent investigations have been published, giving attention to producing mixes based on blends with reactive precursors. The blends commonly involve a Ca-rich precursor such as granulated blast furnace slag (GBFS), and an alumino silicate source such as low calcium fly ash or metakaolin, to form the stable coexistence of calcium silicate hydrate (C-S-H) gels formed from the activation of GBFS and geopolymer gel (also expressed as N-A-S-H) produced from the activation of alumina silicate, which is a cementitious paste that improves the setting and strength properties. ${ }^{23-25}$

Fly ash contains mainly alumina and silica, along with other impurities like iron oxide, lime and magnesia. Due to increased industrial growth fly ash is generated in huge amounts and its accumulation over the years has become a threat to the environment. The utilization of fly ash for preparing geopolymers not only conserves the nature, but also reduces the ever-increasing burden of fly ash on the environment. GBFS is a glassy granular material essentially consisting of oxides like $\mathrm{CaO}, \mathrm{SiO}_{2}$ and $\mathrm{Al}_{2} \mathrm{O}_{3}$. It is formed when molten blast-furnace slag, a byproduct in the extraction of iron is cooled, usually by immersion in water and then ground fine to improve its reactivity. ${ }^{18,26-30}$ There is a relatively small number of research reports expressing the structure and performance of alkali-activated GBFS/Fly ash blends cured at ambient environment, and have been mainly discussed where fly ash is added to GBFS to enhance the strength and microstructure, which leads to a good durability. The durability of these binders in an acid and chloride environment was not investigated before; however, there is an opinion that geopolymer materials have excellent resistance in acid and chloride environments. The above resistance against acid and chloride is an important durability property concerned with serviceability for geopolymer materials used in the construction industry. T. Bakerev ${ }^{31}$ studied the resistance of geopolymer materials prepared from fly ash against $5 \%$ sulphuric acid up to 5 months exposure and concluded that geopolymer materials have better resistance than ordinary cement concretes. Portland cement and blended cement concretes show a deterioration when exposed to acid and chloride environments. The demand of standard methods to evaluate the performance of cements in acid environments has led to research in different exposure conditions by various researchers making it difficult to correlate the results. ${ }^{32}$

This paper presents an investigation of acid and chloride attack on geopolymer materials prepared using GBFS blended with low calcium fly ash in different percentages and sodium hydroxide, sodium silicate as activators and cured in ambient conditions $\left(25 \pm 5^{\circ} \mathrm{C}\right)$. The effects of the fly ash addition to GBFS, weight change, visual appearance, microstructure and strength properties have also been studied. To study the microstructure methods such as SEM with EDAX have been employed. An attempt has been made to correlate the structure with reaction and properties.

\section{EXPERIMENTAL PART}

\subsection{Materials}

The class F fly ash (as per ASTM C618-99) obtained from Ennore power plant and GBFS obtained from M/s Jindal, Karnataka were used for the study. The chemical analysis of GBFS and fly ash were made using the XR fluorescence method and the results were shown in Table 1. Coarse aggregate of maximum $20 \mathrm{~mm}$ with a specific gravity of 2.67 was used. Locally available river sand confirming to Zone II (as per IS 383) with a specific gravity of 2.52 was used for the study. Sodium hydroxide in the form of flakes having a purity of $90 \%$ and sodium silicate in the liquid having a chemical composition of $\mathrm{Na}_{2} \mathrm{O}=14.7 \% \mathrm{SiO}_{2}=29.4 \% \mathrm{H}_{2} \mathrm{O}=55.9 \%$ by mass. To improve the workability of fresh concrete a superplasticizer Glenium supplied by BASF, a polycarboxylic ether is added with the ingredients.

\subsection{Test variables}

Fly ash with GBFS of various mixture proportions were subjected to geopolymerization. However the ratio of $\mathrm{SiO}_{2}$ to $\mathrm{Al}_{2} \mathrm{O}_{3}$ is maintained at approximately 2, which is a typical ratio for a geopolymer structure. Details of the batch compositions are given in Table 2 . The ratio of sodium silicate solution to sodium hydroxide by mass was kept as 2.5 , the ratio of alkaline liquid to the geopolymer solids was kept as 0.4 and water to geopolymer

Table 1: Raw materials chemical properties

Tabela 1: Kemijske lastnosti sestavnih materialov

\begin{tabular}{|c|c|c|c|c|c|c|c|c|c|}
\hline \multirow{2}{*}{ Materials } & \multicolumn{8}{|c|}{ Chemical composition, in mass fractions $(w / \%)$} \\
\cline { 2 - 11 } & $\mathrm{SiO}_{2}$ & $\mathrm{Al}_{2} \mathrm{O}_{3}$ & $\mathrm{CaO}$ & $\mathrm{Fe}_{2} \mathrm{O}_{3}$ & $\mathrm{MgO}$ & $\mathrm{SO}_{3}$ & $\mathrm{Na}_{2} \mathrm{O}$ & $\mathrm{K}_{2} \mathrm{O}$ & LOI \\
\hline GBFS & 34.60 & 17.40 & 33.01 & 1.50 & 8.70 & 0.05 & 1.25 & 0.83 & 1.39 \\
\hline Fly ash & 53.80 & 21.20 & 0.90 & 17.00 & 3.50 & 1.50 & - & - & 0.48 \\
\hline
\end{tabular}


Table 2: Batch composition

Tabela 2: Sestava posamezne serije

\begin{tabular}{|c|c|c|c|c|}
\hline \multirow[t]{2}{*}{ Test variables } & \multicolumn{2}{|c|}{$\begin{array}{c}\text { Batch composition ratio } G B F S \text { \& fly ash, in mass } \\
\text { fractions }(w / \%)\end{array}$} & \multirow[t]{2}{*}{$\mathrm{SiO}_{2} / \mathrm{Al}_{2} \mathrm{O}_{3}$ ratio } & \multirow[t]{2}{*}{$\mathrm{CaO} \%$} \\
\hline & $G B F S$ & Fly ash & & \\
\hline GPCA & 100 & 0 & 1.99 & 33.01 \\
\hline GPCB & 90 & 10 & 2.05 & 29.80 \\
\hline GPCC & 80 & 20 & 2.12 & 26.59 \\
\hline GPCD & 70 & 30 & 2.18 & 23.38 \\
\hline GPCE & 60 & 40 & 2.23 & 20.17 \\
\hline GPCF & 50 & 50 & 2.28 & 16.96 \\
\hline
\end{tabular}

Table 3: Designation of test variables and mix proportions

Tabela 3: Oznaka preizkusnih spremenljivk in razmerja mešanic

\begin{tabular}{|c|c|c|c|c|c|c|c|c|c|c|}
\hline \multicolumn{3}{|c|}{$\begin{array}{c}\text { Test variables ID in different } \\
\text { environment }\end{array}$} & \multicolumn{2}{|c|}{ Binder composition } & \multicolumn{6}{|c|}{ Ingredient contents $\mathrm{kg} / \mathrm{m}^{3}$} \\
\hline $\begin{array}{l}\text { Ambient } \\
\text { curing }\end{array}$ & $\begin{array}{l}\text { Sulphuric } \\
\text { acid }\end{array}$ & $\begin{array}{l}\text { Sodium } \\
\text { chloride }\end{array}$ & $\begin{array}{c}\text { GBFS } \\
\%\end{array}$ & $\begin{array}{c}\text { Fly ash } \\
\%\end{array}$ & $G B F S$ & Fly ash & $\begin{array}{c}\text { Sodium } \\
\text { hydroxide } \\
\text { solution }\end{array}$ & $\begin{array}{l}\text { Sodium } \\
\text { silicate } \\
\text { solution }\end{array}$ & $\begin{array}{c}\text { Coarse } \\
\text { aggregate }\end{array}$ & $\begin{array}{c}\text { Fine } \\
\text { aggregate }\end{array}$ \\
\hline GPCA & GPCAA & GPCAC & 100 & 0 & 400 & 0 & 46 & 115 & 1200 & 645 \\
\hline GPCB & GPCBA & GPCBC & 90 & 10 & 360 & 40 & 46 & 115 & 1200 & 645 \\
\hline GPCC & GPCCA & GPCCC & 80 & 20 & 320 & 80 & 46 & 115 & 1200 & 645 \\
\hline GPCD & GPCDA & GPCDC & 70 & 30 & 280 & 120 & 46 & 115 & 1200 & 645 \\
\hline GPCE & GPCEA & GPCEC & 60 & 40 & 240 & 160 & 46 & 115 & 1200 & 645 \\
\hline GPCF & GPCFA & GPCFC & 50 & 50 & 200 & 200 & 46 & 115 & 1200 & 645 \\
\hline
\end{tabular}

solids as 0.24 . The properties of various concrete mixes are shown in Table 3.

\subsection{Sample preparation for physical testing}

Solutions of $\mathrm{NaOH}$ (12-M concentration) and $\mathrm{Na}_{2} \mathrm{SiO}_{3}$ were separately prepared $24 \mathrm{~h}$ before casting. Both the solutions were mixed together at the time of mixing. A weighed quantity of GBFS, fly ash, fine aggregate and coarse aggregate were dry mixed in a pan for about $3 \mathrm{~min}$ to $5 \mathrm{~min}$. Wet mixing was done for another 3 mins and the required quantity of super plasticizer and water was added to obtain the required consistency. The samples were then cast into the steel moulds of size $100 \mathrm{~mm} \times 100 \mathrm{~mm} \times 100 \mathrm{~mm}$. Compaction was done by manual strokes, followed by a compaction on a vibrating table for $20 \mathrm{~s}$. The cubes were remoulded after $24 \mathrm{~h}$ and cured at a relative humidity of $25 \pm 5^{\circ} \mathrm{C}$ to prevent drying effects. The required number of samples for each mix was prepared and cured under ambient conditions and were reported as the mean of the three samples.

\subsection{Test procedure}

The resistance of the materials to acid and chloride attack was studied by immersion of the cubical specimens of size $(100 \mathrm{~mm} \times 100 \mathrm{~mm} \times 100 \mathrm{~mm})$ in a $5 \%$ solution of concentrated sulphuric acid for acid attack and with a proportion of $4 \% \mathrm{NaCl}$ with $1 \%$ magnesium sulphate solution for chloride attack for a period up to $180 \mathrm{~d}$. The compressive strength was determined before the test and after $(28,60,120$ and 180) d of exposure. The choice of acid solution and its concentration was based on the practical application of concrete as a construction material mainly in the sewage pipe and mining industries. The volume of solution was kept not less than four times the volume of the specimens immersed and maintained throughout the test period. The testing solutions were replaced with new solutions after $30 \mathrm{~d}$ until the completion of the test period. The samples were compared with all the grades of concrete that were ambient cured.

The deterioration of samples was studied by SEM with EDAX. For this testing, the samples were taken from the surface at a $0-5-\mathrm{mm}$ depth, exposed to the solutions of $120 \mathrm{~d}$ and compared with conventional ambient cured samples. The SEM analysis was done using a microscope having a magnification of $5 \times$ to $3,00,000 \times$ with a voltage of $0.3-30 \mathrm{kV}$. The coating of the samples for the analysis was done using an ion sputter with a gold target and the system was attached with the latest PIV. The resolution of the equipment varied from $3 \mathrm{~nm}, 4 \mathrm{~nm}$ to $10 \mathrm{~nm}$. The change in mass before and after the immersion was observed for all the samples.

\section{RESULTS AND DISCUSSION}

\subsection{Visual appearance}

Visual appearances of geopolymer specimens after immersion in a solution of concentrated sulphuric acid after $180 \mathrm{~d}$ are shown in the Figure 1. Its appearance 


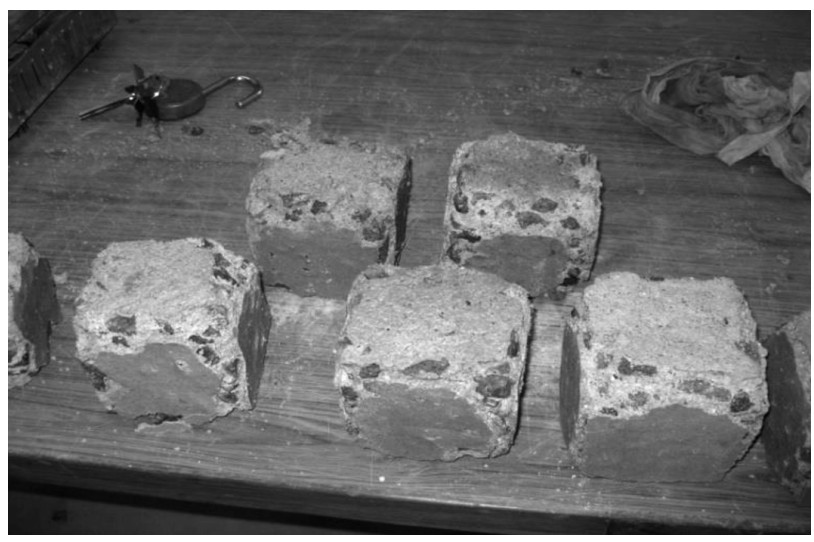

Figure 1: GPC samples after $180 \mathrm{~d}$ in sulphuric acid Slika 1: Vzorci GPC po 180 dneh v žvepleni kislini

seems to be very slightly changed after $28 \mathrm{~d}$, but there is a distinct change in the appearance of the deterioration after $180 \mathrm{~d}$. The surface became softer as the duration of the test period prolonged, but could not be scratched with finger nails. The deterioration of the surface increased with the duration, but the amount of deterioration could not be determined through a visual inspection. ${ }^{31}$

The geopolymer specimens immersed in chloride solution did not reveal any changes in the surface after $28 \mathrm{~d}$. Even after $180 \mathrm{~d}$ also, there is no severe deterioration.

\subsection{Change in weight}

Table 4 and Figure 2 give the comparative weight changes for the specimens exposed to sulphuric acid and chloride solution with the ambient cured samples after $180 \mathrm{~d}$. In ambient cured samples there is a loss of weight with the replacement of fly ash to GBFS. The percentage of loss increases with the percentage of replacement. The loss of weight at $10 \%$ replacement of fly ash to GBFS is $1.512 \%$ and $1.678 \%$ with $50 \%$ replacement (GBFC). But at $40 \%$ replacement there is loss of weight of only $1.369 \%$, which shows the optimum replacement of fly ash. This may be due to the limitations of the $\mathrm{SiO}_{2} / \mathrm{Al}_{2} \mathrm{O}_{3}$ ratio. The geopolymer samples (GPCA) immersed in sulphuric acid solution show a little loss of weight 0.05 $\%$. The samples with the replacement of fly ash to GBFS show a loss of $0.43 \%$ at $10 \%$ with a gain of $0.88 \%$ at

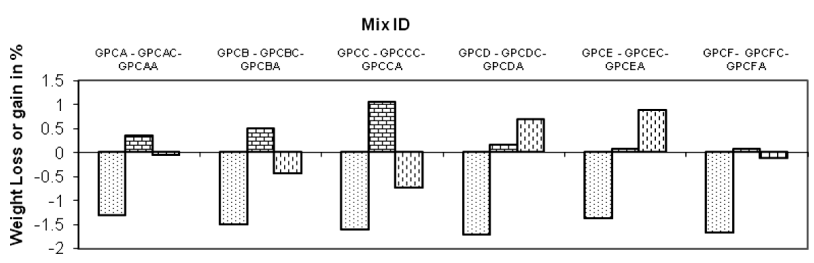

Figure 2: Weight change in $\%$ ambient curing with $\mathrm{NaCl} \& \mathrm{H}_{2} \mathrm{SO}_{4}$ after $180 \mathrm{~d}$

Slika 2: Spreminjanje teže v \% pri 180 dnevni izpostavitvi okolju z $\mathrm{NaCl}$ in $\mathrm{H}_{2} \mathrm{SO}_{4}$
$40 \%$ replacement. Similar observations have been reported by ${ }^{31}$. The mass change was calculated according to ASTM C267. All the geopolymer concrete mixes show a very low mass loss of less than $3 \%$.

Table 4: Weight change in $\%$ ambient curing with $\mathrm{NaCl} \&$ sulphuric acid after $180 \mathrm{~d}$

Tabela 4: Sprememba teže v \% po 180 dneh izpostavitve okolju z $\mathrm{NaCl}$ in žvepleno kislino

\begin{tabular}{|l|c|c|c|}
\hline \multicolumn{1}{|c|}{ Test variables Id } & \multicolumn{3}{c|}{ Weight change, \% } \\
\hline GPCA - GPCAC-GPCAA & -1.32 & 0.35 & -0.05 \\
\hline GPCB - GPCBC-GPCBA & -1.512 & 0.49 & -0.43 \\
\hline GPCC - GPCCC-GPCCA & -1.622 & 1.05 & -0.73 \\
\hline GPCD - GPCDC-GPCDA & -1.715 & 0.16 & 0.69 \\
\hline GPCE - GPCEC-GPCEA & -1.369 & 0.08 & 0.88 \\
\hline GPCF- GPCFC-GPCFA & -1.678 & 0.08 & -0.12 \\
\hline
\end{tabular}

The geopolymer samples with GBFS (GPCA) immersed in chloride solution gain weight to $0.35 \%$. When it is replaced by fly ash to GBFS it gains weight, which varied from $0.35 \%$ at $10 \%$ replacement to a very low gain of $0.08 \%$ at $50 \%$ replacement. The gain in $\%$ increases with the increase of the replacement. But it shows a low value in $40 \%$ and $50 \%$ of $0.08 \%$. A minimal change in nominal weight loss has been observed with $40 \%$ fly ash in the geopolymer composite, which indicates that $40 \%$ fly ash composite with geopolymer performs the best, compared to all the other compositions. The specimens were damaged beyond this $40 \%$ fly ash and longer durations of immersion, which is in good agreement with $^{33}$. Interaction of geopolymer in the acid solution may result in replacement of exchangeable cations such as $\mathrm{Na}^{+}$in the polymer by hydrogen ion or hydronium ion. ${ }^{31}$

\subsection{Compressive strength}

Figure 3 shows the variation of compressive strength of samples for different duration periods in ambient curing. The compressive strength increases with time in all the mixes. The geopolymer concrete with $100 \%$ GBFS (GPC-A) shows a higher compressive strength of $74 \mathrm{MPa}$ at $180 \mathrm{~d}$. Its strength varies from $37 \mathrm{MPa}$ at $3 \mathrm{~d}$ to $74 \mathrm{MPa}$ at $180 \mathrm{~d}$. The increase in percentage was 100 , which is in good agreement with S. A. Bernal. ${ }^{34}$ The geopolymer concrete GBFS blended with fly ash at $10 \%$ replacement (GPC-B) strength varies from $32.4 \mathrm{MPa}$ at 3

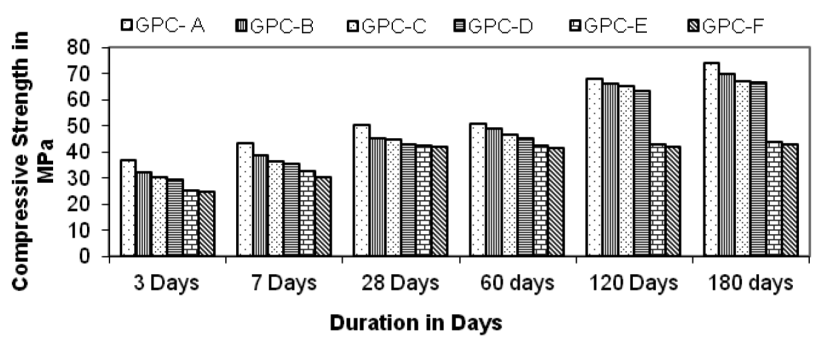

Figure 3: Compressive strength of GPC Slika 3: Tlačna trdnost GPC 


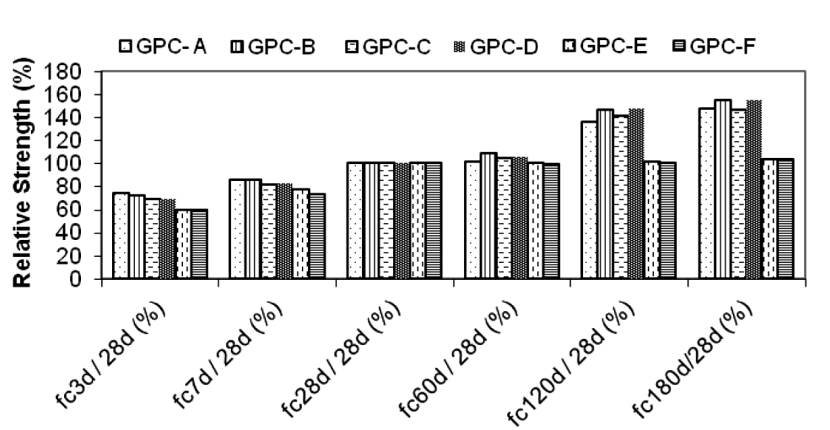

Figure 4: Compressive strength development Slika 4: Razvoj tlačne trdnosti

d to $69.8 \mathrm{MPa}$ at $180 \mathrm{~d}$. Similarly, other replacement levels $20 \%, 30 \%$ (GPC-C, GPC-D) strength varies 30.5, $29.6 \mathrm{MPa}$ at $3 \mathrm{~d}$ to $67,66 \mathrm{MPa}$ at $180 \mathrm{~d}$, respectively. In the above, replacement levels of fly ash to GBFS the percentage increase is $120 \%$. But at $40 \%$ and $50 \%$ (GPC-E, GPC-F) replacement levels its strength at $180 \mathrm{~d}$ was $44 \mathrm{MPa}$ and $43 \mathrm{MPa}$, respectively, with a percentage increase of $73 \%$. The rate of development of strength at $180 \mathrm{~d}$ with reference to $28 \mathrm{~d}$ is $150 \%$ in all the mixes, except in the mixes of GPC-E, GPC-F, which show only $100 \%$, as in Figure 4.

\subsection{Effect of sulphuric acid and chloride}

Figure 5 show the evaluation of compressive strength for different duration periods for the samples immersed in a solution sodium chloride. It reveals that the reduction of strength is more with an increase in the percentage of replacement of fly ash to GBFS in the geopolymer concrete. The strength reduction rate increases with the duration period in all the mixes. The reduction rate from $28 \mathrm{~d}$ to $60 \mathrm{~d}$ is more and it is further increased at $120 \mathrm{~d}$. The reduction of strength of geopolymer concrete with $100 \%$ GBFS (GPC-A) is $42 \%$ compared to the ambient cured samples at $180 \mathrm{~d}$. There is a minimum reduction of strength from $120 \mathrm{~d}$ to $180 \mathrm{~d}$. The GPC blended with fly ash at $10 \%$ replacement (GPC-B) shows a reduction of strength $40 \%$ at $180 \mathrm{~d}$. Similarly, other replacement levels $20 \%, 30 \%$ (GPC-C, GPC-D) show a strength reduction of $47 \%$ and $45 \%$ respectively at $180 \mathrm{~d}$. In the replacement of fly ash to GBFS, $40 \%$ replacement performs well and shows a reduction rate of $24 \%$. This shows that GBFS can be replaced by $40 \%$ of fly ash as

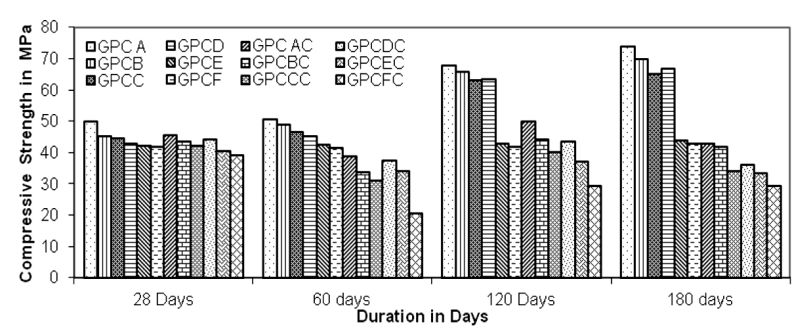

Figure 5: Compressive strength comparison of ambient curing with $\mathrm{NaCl}$

Slika 5: Primerjava tlačne trdnosti pri utrjevanju v okolju z NaCl

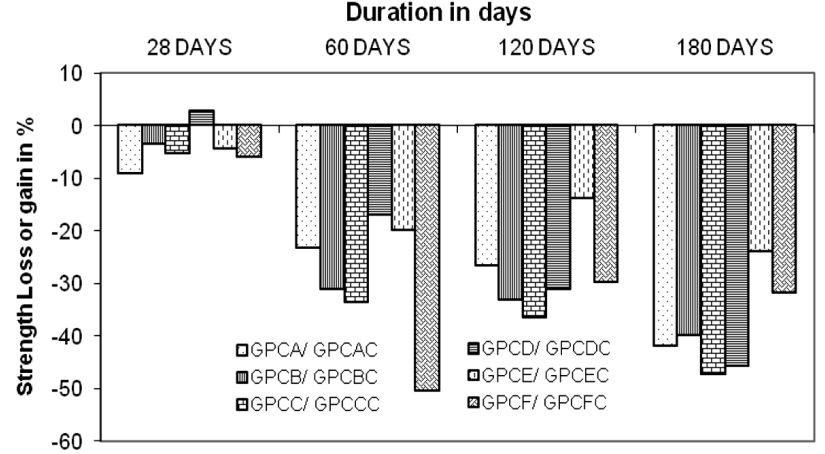

Figure 6: Strength change in $\%$ ambient curing with $\mathrm{NaCl}$ Slika 6: Spreminjanje trdnosti v \% pri utrjevanju v okolju z $\mathrm{NaCl}$

the reduction rate is less compared to GPC with $100 \%$ GBFS. The reactivity of fly ash in the chloride environment is good. The detailed loss or gain in \% is shown in Table 5 and Figure 6.

Table 5: Strength change in $\%$ ambient curing with $\mathrm{NaCl}$ Tabela 5: Spreminjanje trdnosti v \% pri utrjevanju v okolju z $\mathrm{NaCl}$

\begin{tabular}{|c|c|c|c|c|c|c|}
\hline \multirow{2}{*}{ Days } & $\begin{array}{c}\text { GPCA/ } \\
\text { GPCAC }\end{array}$ & $\begin{array}{c}\text { GPCB/ } \\
\text { GPCBC }\end{array}$ & $\begin{array}{c}\text { GPCC/ } \\
\text { GPCC }\end{array}$ & $\begin{array}{c}\text { GPCD/ } \\
\text { GPCDC }\end{array}$ & $\begin{array}{c}\text { GPCE/ } \\
\text { GPCEC }\end{array}$ & $\begin{array}{c}\text { GPCF/ } \\
\text { GPCFC }\end{array}$ \\
\hline 28 & -9.2 & -3.54 & -5.2 & 2.8 & -4.3 & -6 \\
\hline 60 & -23.3 & -31.2 & -33.6 & -17 & -20 & -50.4 \\
\hline 120 & -26.7 & -33.1 & -36.5 & -31.2 & -13.9 & -29.8 \\
\hline 180 & -42 & -40 & -47.4 & -45.7 & -24 & -31.86 \\
\hline
\end{tabular}

Figure 7 shows the evaluation of compressive strength for the different duration periods for the test samples immersed in $5 \%$ solution of sulphuric acid. The reduction rate continuously increases with the duration period. There is a strength reduction of $85 \%$ compared to ambient cured samples for the geopolymer concrete prepared with $100 \%$ GBFS at $180 \mathrm{~d}$. The GPC blended with fly ash at $10 \%$ replacement (GPC-B) shows an $83 \%$ reduction of strength at $180 \mathrm{~d}$. Similarly, other replacement levels $20 \%, 30 \%$ (GPC-C, GPC-D) show a strength reduction of $81 \%$ and $77 \%$, respectively, at $180 \mathrm{~d}$. In the replacement of fly ash to GBFS, $40 \%$ replacement performs well and it shows a reduction rate of $53 \%$. This shows that the replacement of $40 \%$ of fly ash is the optimum. The strength reduction is proportional to the replacement of fly ash. The detailed loss or gain in $\%$ is shown in Table 6 and in Figure 8. Com-

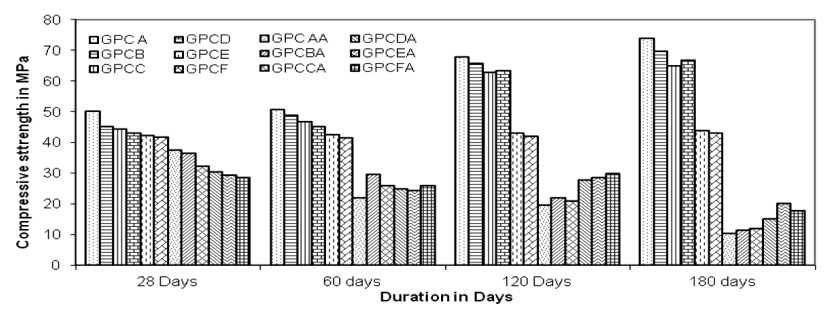

Figure 7: Compressive strength comparison of ambient curing with sulphuric acid

Slika 7: Primerjava tlačne trdnosti po utrjevanju v okolju z žvepleno kislino 
R. GOPALAKRISHNAN, K. CHINNARAJU: DURABILITY OF ALUMINA SILICATE CONCRETE BASED ...

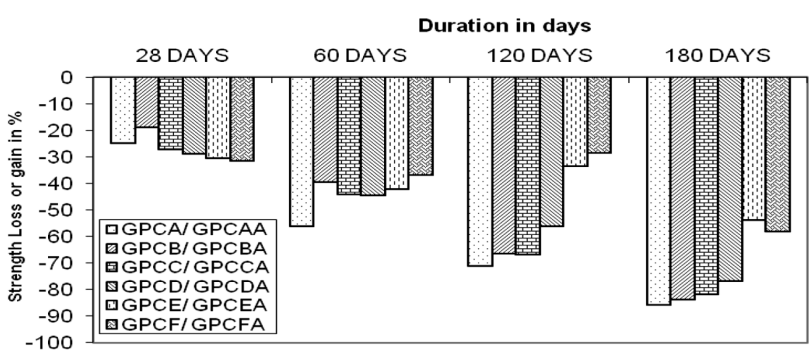

Figure 8: Strength change in $\%$ ambient curing with sulphuric acid Slika 8: Spreminjanje trdnosti v \% pri utrjevanju v okolju z žvepleno kislino

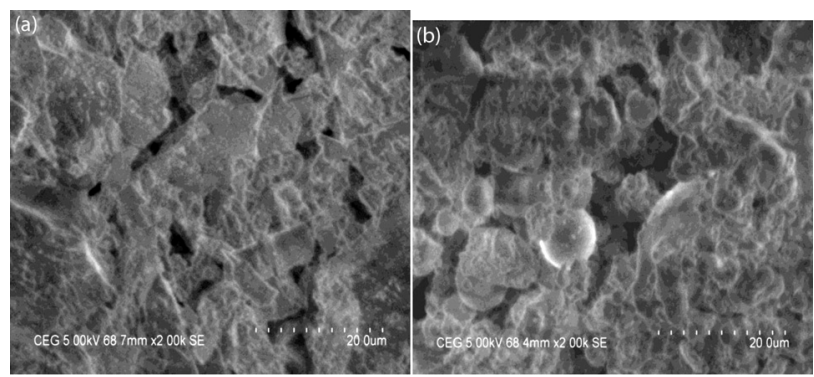

Figure 9: SEM images of: a) GBFS and b) fly ash Slika 9: SEM-posnetek: a) GBFS in b) leteči pepel pressive strength appears to increase for a set of samples with curing time for ambient curing, whereas for the set cured in the $\mathrm{NaCl}$ solution it appears to decrease. This improvement in compressive strength is attributed to the leaching of silica and aluminium at a higher $\mathrm{Ca}$ of $\mathrm{NaOH} \cdot{ }^{36}$

Table 6: Strength change in $\%$ ambient curing with sulphuric acid Tabela 6: Spreminjanje trdnosti v \% pri utrjevanju v okolju z žvepleno kislino

\begin{tabular}{|c|c|c|c|c|c|c|}
\hline Days & $\begin{array}{c}\text { GPCA } / \\
\text { GPCAA }\end{array}$ & $\begin{array}{l}\text { GPCB / } \\
\text { GPCBA }\end{array}$ & $\begin{array}{l}\text { GPCC / } \\
\text { GPCC }\end{array}$ & $\begin{array}{c}\text { GPCD / } \\
\text { GPCDA }\end{array}$ & $\begin{array}{c}\text { GPCE / } \\
\text { GPCEA }\end{array}$ & $\begin{array}{c}\text { GPCF/ } \\
\text { GPCFA }\end{array}$ \\
\hline 28 & -25.1 & -19.1 & -27.4 & -29.1 & -30.5 & -31.7 \\
\hline 60 & -56.4 & -39.6 & -44.1 & -44.7 & -42.3 & -37.1 \\
\hline 120 & -71.2 & -66.6 & -66.8 & -56.2 & -33.5 & -28.5 \\
\hline 180 & -85.8 & -83.7 & -81.7 & -77 & -53.9 & -58.4 \\
\hline
\end{tabular}

The development of the strength of specimens is suppressed due to the hydration of $\mathrm{Ca}-\mathrm{Al}$ - silicates from the dissolution of the CAS phase by the hydroxyl ion $\left(\mathrm{OH}^{\Phi}\right)$ contributed by water and aqueous $\mathrm{NaOH}$ so that the $\mathrm{Al}$ and $\mathrm{Si}$ become penta-valent due to the attachment of $\left(\mathrm{OH}^{\Phi}\right)$. Due to this, $\mathrm{Al}-\mathrm{O}-\mathrm{Al}$ and $\mathrm{Si}-\mathrm{O}-\mathrm{Si}$ tend to
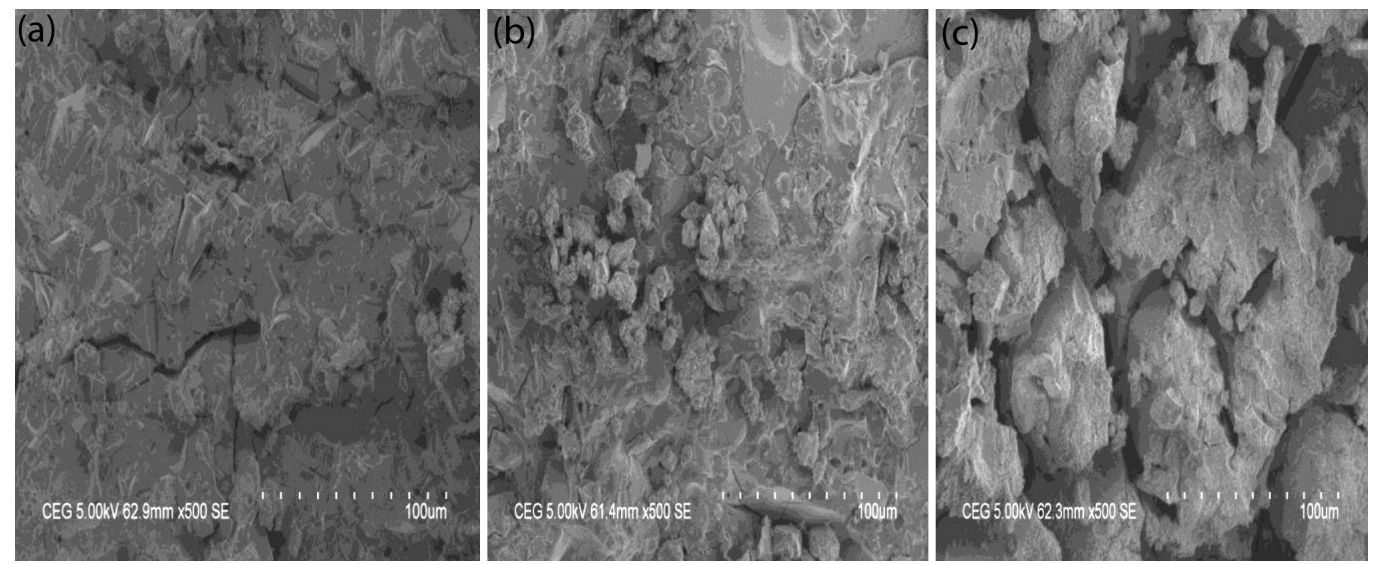

Figure 10: SEM images before immersion: a) GPCA, b) GPCC, c) GPCE Slika 10: SEM-posnetki pred namakanjem: a) GPCA, b) GPCC, c) GPCE
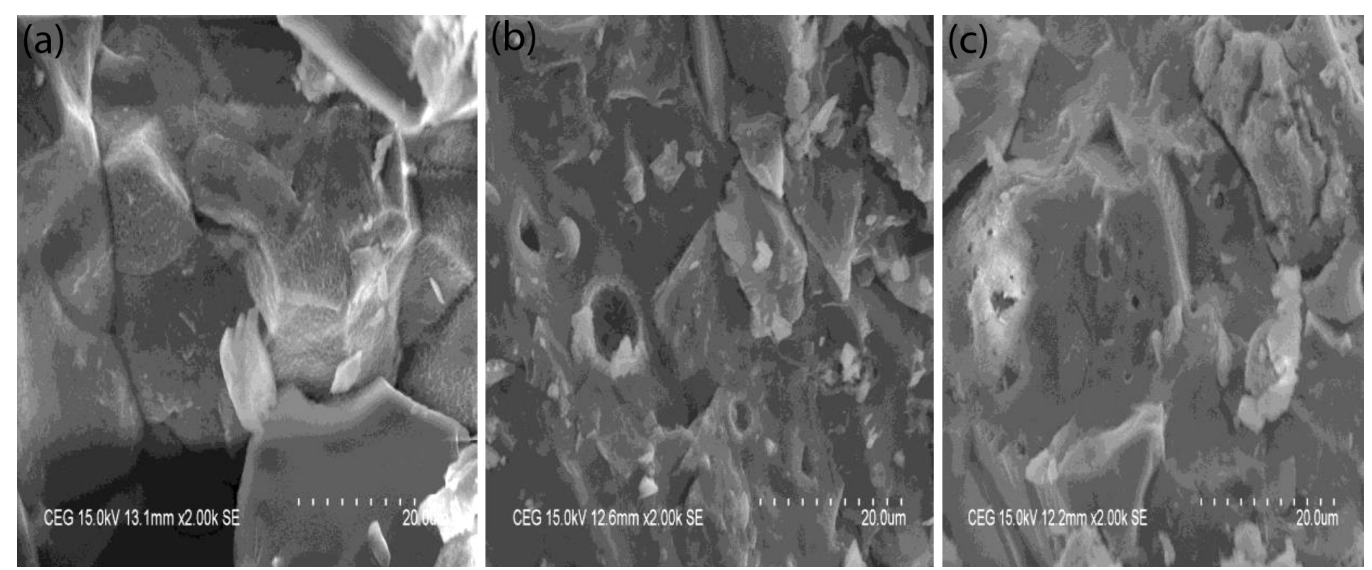

Figure 11: SEM images after immersion in solution of $\mathrm{NaCl}$ for $120 \mathrm{~d}$ : a) GPCAC, b) GPCCC, c) GPCEC

Slika 11: SEM-posnetki po 120 dnevnem namakanju v raztopini NaCl: a) GPCAC, b) GPCCC, c) GPCEC 

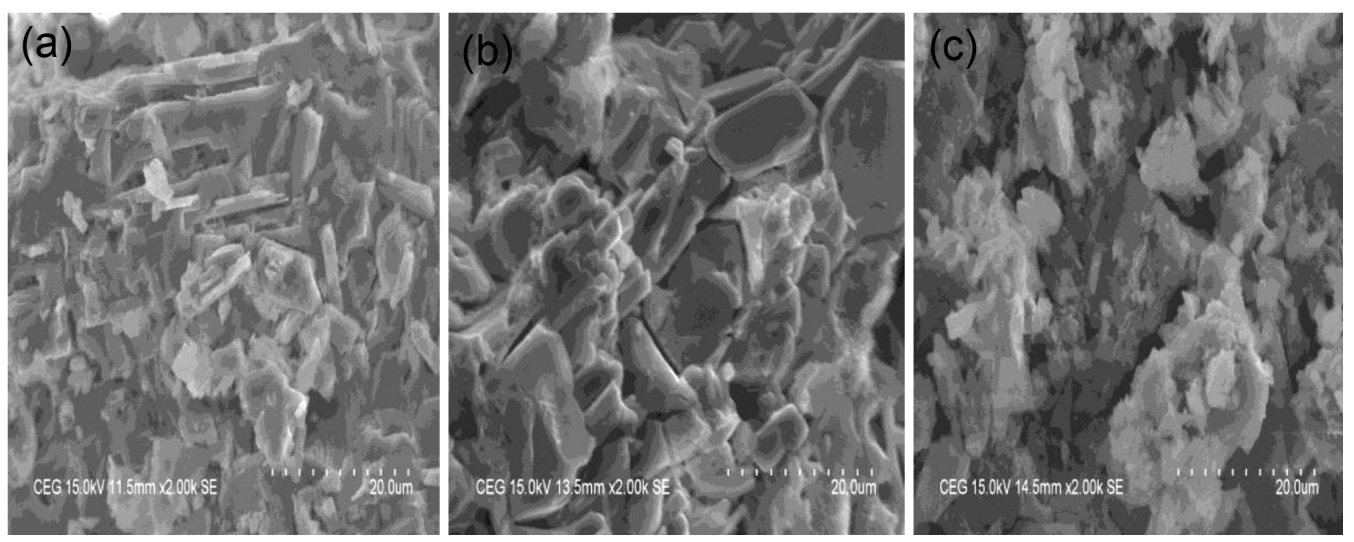

Figure 12: SEM images after immersion in solution of $\mathrm{H}_{2} \mathrm{SO}_{4}$ for 120 d: a) GPCAA, b) GPCCA, c) GPCEA Slika 12: SEM-posnetki po 120 dnevnem namakanju v raztopini $\mathrm{H}_{2} \mathrm{SO}_{4}$ : a) GPCAA, b) GPCCA, c) GPCEA

strengthen the bands. This can be schematically represented as:

$$
\begin{aligned}
& \mathrm{Ca}-\mathrm{Si}-(\mathrm{o}-) \text { o }-\mathrm{Al}-\mathrm{Ca}+20 \mathrm{H}^{\Phi} \\
& (\mathrm{H} 6) \mathrm{Ca}-\mathrm{Si}-\mathrm{o}-\mathrm{Al}-\mathrm{Ca}-\mathrm{OH}^{35}
\end{aligned}
$$

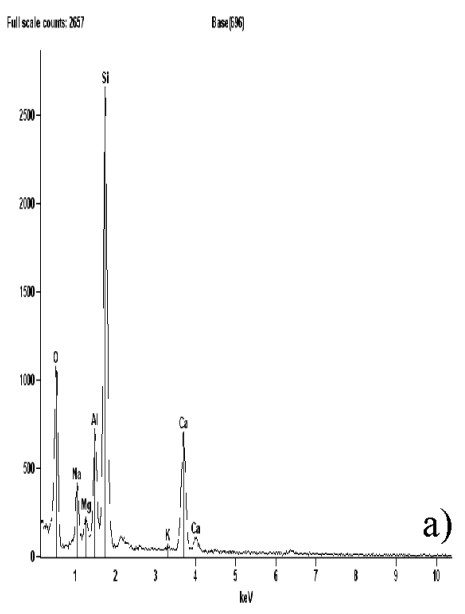

\subsection{SEM with EDAX}

Figure 9 shows the SEM images of GBFS and fly ash. Figure 10 shows the SEM images of the specimens before immersion into the solutions of sulphuric acid and chloride. It is evident that the appearance of gel-like

Figure 13: EDAX spectrum before immersion: a) GPCA, b) GPCC, c) GPCE

Slika 13: EDAX-spekter pred namakanjem: a) GPCA, b) GPCC, c) GPCE

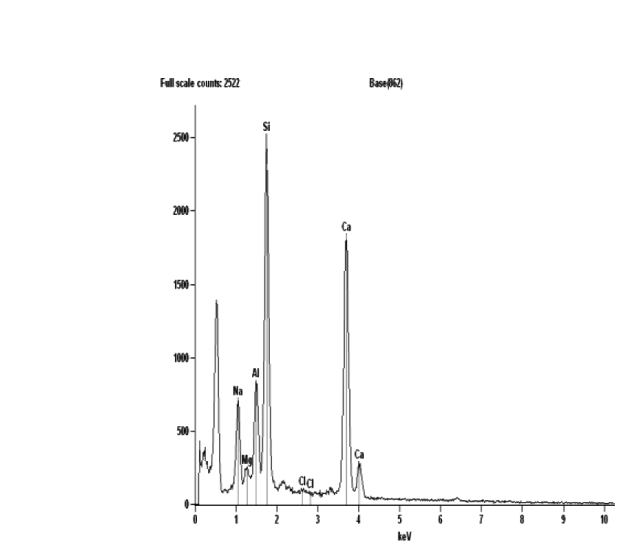

a)
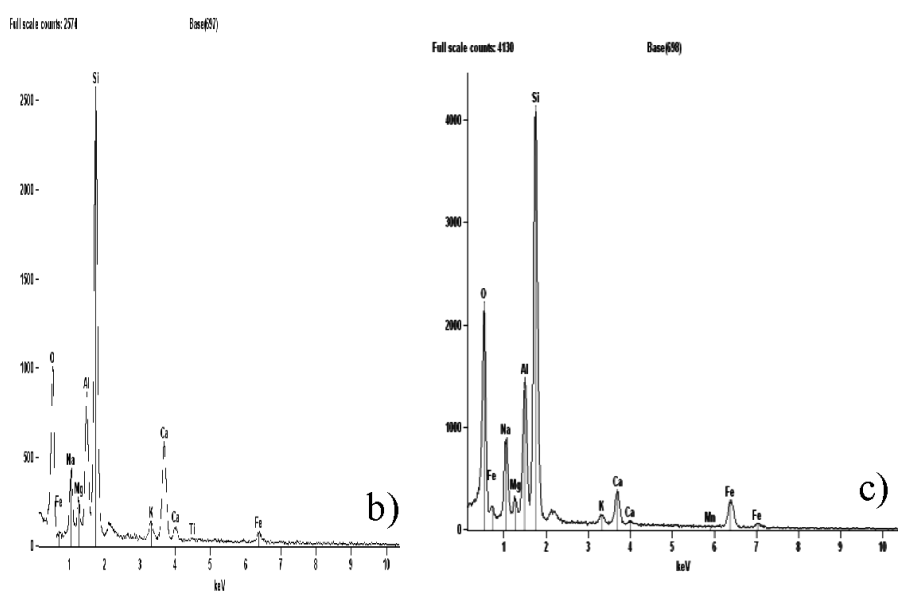

c)

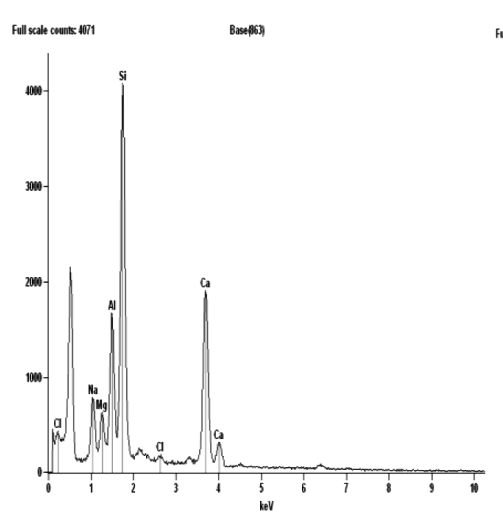

b)

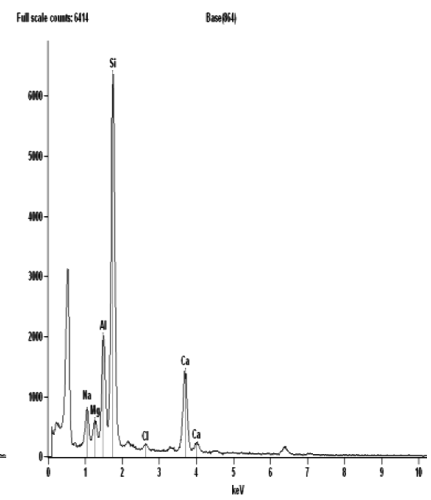

c)

Figure 14: EDAX spectrum after immersion in solution of $\mathrm{NaCl}$ for $120 \mathrm{~d}$ : a) GPCA, b) GPCCC, c) GPCEC Slika 14: EDAX-spekter po 120 dnevnem namakanju v NaCl: a) GPCA, b) GPCCC, c) GPCEC 


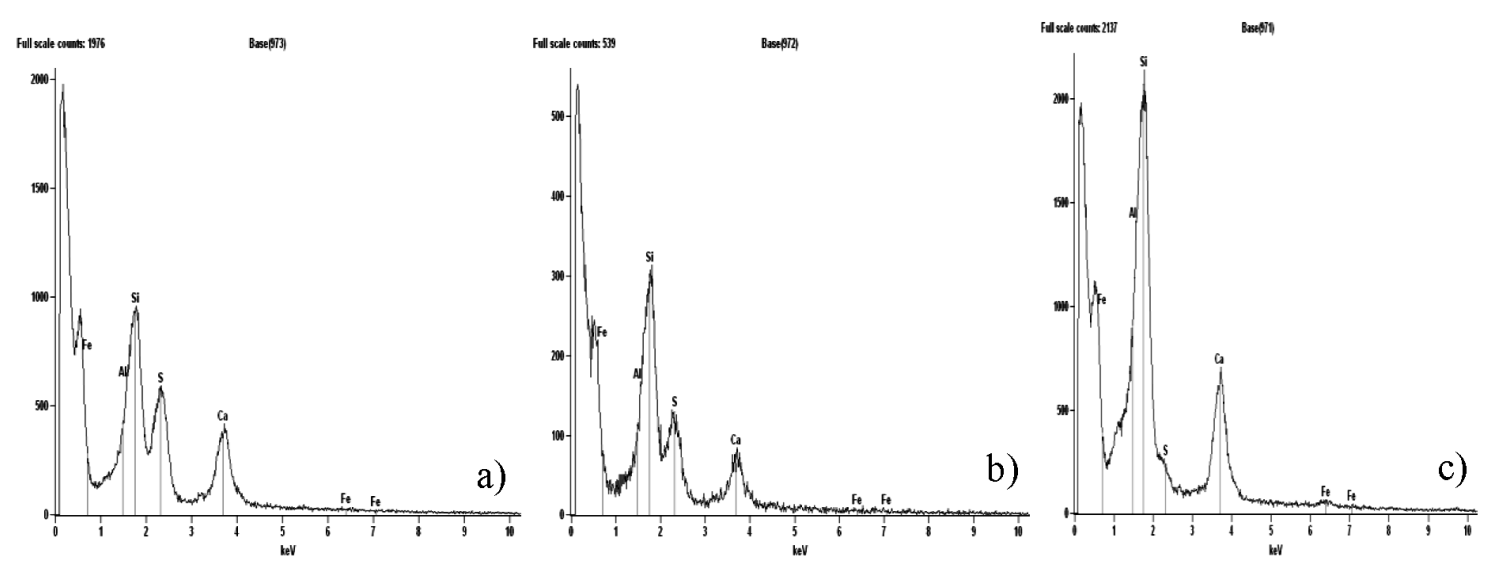

Figure 15: EDAX spectrum after immersion in solution $\mathrm{H}_{2} \mathrm{SO}_{4}$ for $120 \mathrm{~d}$ : a) GPCAA, b) GPCCA, c) GPCEA Slika 15: EDAX-spekter po 120 dnevnem namakanju v raztopini H2SO4: a) GPCAA, b) GPCCA, c) GPCEA

phases in the microstructure (of the SEM) can be attributed to the development of the microstructure particularly in the GBFS phases. ${ }^{6}$

The immersion in $\mathrm{NaCl}$ for the $120 \mathrm{~d}$ period appears to cause a decrease in $\mathrm{Na}$ content of the samples, which may be due to the migration of $\mathrm{Na}^{+}$ions from the specimen samples to $\mathrm{NaCl}$. The microstructures of the specimen samples after $120 \mathrm{~d}$ of immersion in a solution of $\mathrm{NaCl}$ were studied using SEM and the results are shown in Figure 11.

SEM images of the samples after immersion in $\mathrm{H}_{2} \mathrm{SO}_{4}$ for $120 \mathrm{~d}$ (Figure 12) indicate that there is a formation of light-coloured precipitates in the sample after immersion in $\mathrm{H}_{2} \mathrm{SO}_{4}$ solution. The formation of lightcoloured precipitates is indicative of the degradation of the cured specimen. ${ }^{36}$ The appearance of lightly coloured precipitates in a low distribution may be attributed to a more amorphous, less-crystalline layer formation. ${ }^{6}$

A comparison of the EDAX patterns of the samples before immersion and also after immersion in the $\mathrm{NaCl}$ and $\mathrm{H}_{2} \mathrm{SO}_{4}$ media indicates the following:

The parent samples as prepared contain Magnesium as is evident from Figure 13, but this magnesium content is retained even after immersion in $\mathrm{NaCl}$, as evident from the Figure 14 after immersion.

The magnesium content of the samples was found to be lost during immersion in the solution of $\mathrm{H}_{2} \mathrm{SO}_{4}$ after $120 \mathrm{~d}$, which is shown in Figure 15. This fall is in the magnesium content of the samples in $\mathrm{H}_{2} \mathrm{SO}_{4}$. Immersion may be attributed to the migration of $\mathrm{Mg}^{2+}$ from the samples to the $\mathrm{H}_{2} \mathrm{SO}_{4}$ medium forming $\mathrm{MgSO}_{4}$ (soluble). The results are good agreement with previous literatures. ${ }^{36}$

\section{CONCLUSION}

From the experimental investigation the following conclusions can be drawn. There is an improvement in strength with respect to the age observed for a maximum period of $180 \mathrm{~d}$ in all the mixes. The geopolymer con- crete with GBFS (100\%) performed better than the other mixes with fly ash and GBFS combination during ambient curing. A geopolymer concrete mix with $40 \%$ replacement of fly ash to GBFS performed well in chloride environment with a reduction of $24 \%$ in comparison to the geopolymer concrete with GBFS (100\%) having a reduction rate of $42 \%$. The geopolymer concrete mix with $40 \%$ replacement of fly ash to GBFS performed well in the acid environment with a reduction rate of $53 \%$ in comparison to geopolymer concrete prepared with GBFS $(100 \%)$ has a reduction rate of $85 \%$. In general, the reduction rate increases with the increase in replacement levels of fly ash to GBFS in the geopolymer concrete in both the chloride and acid environment. The SEM and EDAX images after $120 \mathrm{~d}$ of immersion in acid and chloride environment show the deterioration, same as that of previous researchers. The geopolymer concrete prepared with GBFS can be replaced by fly ash (40\%) as it performs equally well and satisfies all the durability properties in both the chloride and acid environments.

\section{Acknowledgement}

The authors are very thankful to the management of Sri Venkateswara college of Engineering, Sri Perumbudur and College of Engineering Guindy, Anna University, Chennai for providing facilities to carry out the work.

\section{REFERENCES}

${ }^{1}$ B. V. Rangan, D. Hardjto, Development and properties of low calcium fly ash based Geopolymer concrete, Research report GC-1, Faculty of Engineering, Curtin's University of Technology, Perth, Australia 2005

${ }^{2}$ P. Duxson, A. Fernandez-Jimenez, J. L. Provis, G. C. Lukey, A. Palomo, J. S. J. Van Deventer, Geopolymer technology: the current state of the art, Journal of Materials Science, 42 (2007) 9, 2917-2933, doi:10.1007/s10853-006-0637-z

${ }^{3}$ J. L. Provis, G. C. Lukey, J. S. J. van Deventer, Do geopolymers actually contain nanocrystalline zeolites? A reexamination of existing results, Chem. Mater., 17 (2005) 12, 3075-3085, doi:10.1021/cm050230i 
${ }^{4}$ P. Duxson, J. L. Provis, G. C. Lukey, J. S. J. Van Deventer, The role of inorganic polymer technology in the development of "Green Concrete", Cement and Concrete Research, 37 (2007) 12, 1590-1597, doi:10.1016/j.cemconres.2007.08.018

${ }^{5}$ T. W. Cheng, J. P. Chiu, Fire-resistant geopolymer produced by granulated blast furnace slag, Minerals Engineering, 16 (2003) 3, 205-210, doi:10.1016/S0892-6875(03)00008-6

${ }^{6}$ T. Bakharev, Durability of Geopolymer Materials in Sodium and Magnesium Sulfate Solutions, Cement and Concrete Research, 35 (2005) 6, 1233-1246, doi:10.1016/j.cemconres.2004.09.002

${ }^{7}$ M. Sofi, J. S. J. van Deventer, P. A. Mendis, G. C. Lukey, Engineering properties of inorganic polymer concretes (IPCs), Cement and Concrete Research, 37 (2007) 2, 251-57, doi:10.1016/ j.cemconres.2006.10.008

${ }^{8}$ J. Davidovits, Geopolymer chemistry and application, Institute of Geopolymer, 16 rue GalileeF-02100 Saint Quentin, France, 2008, 585

${ }^{9}$ K. Somna, C. Jaturapitakkul, P. Kajitvichyanukul, P. Chindaprasirt, $\mathrm{NAOH}$-activated ground fly ash geopolymer cured at ambient temperature, Fuel, 90 (2011) 6, 2118-2124, doi:10.1016/j.fuel.2011. 01.018

${ }^{10} \mathrm{~S}$. Ahmari, L. Zhang, Production of eco-friendly bricks from copper mine tailings through geopolymerization, Construction and Building Materials, 29 (2012), 323-331, doi:10.1016/j.conbuildmat. 2011.10.048

${ }^{11}$ T. Tho-in, V. Sata, P. Chindaprasirt, C. Jaturapitakkul, Pervious high-calcium fly ash geopolymer concrete, Construction and Building Materials, 30 (2012), 366-371, doi:10.2016/j.conbuildmat. 2011.12.028

${ }^{12}$ W. D. A. Rickard, J. Temuujin, A. van Riessen, Thermal analysis of geopolymer pastes synthesised from five fly ashes of variable composition, Journal of Non-Crystalline Solids, 358 (2012) 15, 1830-1839, doi:10.1016/j.jnoncrysol.2012.05.032

${ }^{13}$ F. Škvara, L. Kopecky, J. Nemeček, Z. Bittnar, Microstrucure of geopolymer materials based on fly ash, Ceramics - Silikaty, 50 (2006) 4, 208-215

${ }^{14}$ A. Fernandez-Jimenez, I. Garcia-Lodeiro, A. Palamo, Durability of alkali-activated fly ash cementitious materials, Jornal of Materials Science, 42 (2007) 9, 3055-3065, doi:10.1007/s10853-006-0584-8

${ }^{15}$ N. W. Chen-Tan, A. van Riessen, C. V. Ly., D. C. Southam, Determining the reactivity of a fly ash for production of geopolymer, J. Am. Ceram. Soc., 92 (2009) 4, 881-887, doi:10.1111/j.1551-2916. 2009.02948x

${ }^{16}$ X. Guo, H. Shi, W. Dick, Use of heat treated water treatment residuals in fly ash-based geopolymers, J. Am. Ceram. Soc., 93 (2010) 1, 272-278, doi:10.1111/j.1551-2916.2009.03331x

${ }^{17}$ M. Guerrieri, J. G. Sanjayan, Behaviour of combined fly ash/slagbased geopolymers when exposed to high temperatures, Fire and Materials, 34 (2010) 4, 163-175, doi:10.1002/fam.1014

${ }^{18}$ S. K. Nath, S. Kumar, Influence of iron making slags on strength and microstructure of fly ash geopolymer, Construction and Building Materials, 38 (2013), 924-930, doi:10.1016/j.conbuildmat.2012. 09.070

${ }^{19}$ P. Duxson, S. W. Mallicoat, G. C. Lukey, W. M. Kriven, J. S. J. van Deventer, The effect of alkali and $\mathrm{Si} / \mathrm{Al}$ ratio on the development of mechanical properties of metakaolin-based geopolymers, Colloids and Surfaces A, 292 (2007) 1, 8-20, doi:10.1016/j.colsurfa.2006. 05.044

${ }^{20}$ P. Chindaprasirt, C. Jaturapitakkul, W. Chalee, U. Rattanasak, Comparative study on the characteristics of fly ash and bottom ash geopolymers, Waste Management, 29 (2009) 2, 539-543, doi:10.1016/ j.wasman.2008.06.023
${ }^{21}$ P. Duxson, J. L. Provis, G. C. Lukey, S. W. Mallicoat, W. M. Kriven, J. S. J. van Deventer, Understanding the relationship between geopolymer composition, microstructure and mechanical properties, Colloids and Surfaces A, 269 (2005) 1-3, 47-58, doi:10.1016/ j.colsurfa.2005.06.060

${ }^{22}$ J. Wongpa, K. Kiattikomol, C. Jaturapitakkul, P. Chindaprasirt, Compressive strength, modulus of elasticity, and water permeability of inorganic polymer concrete, Materials and Design, 31 (2010) 10 , 4748-4754, doi:10.1016/j.matdes.2010.05.012

${ }^{23}$ C. Shi, A. Fernandez-Jimenez, A. Palomo, New cements for the $21^{\text {st }}$ Century: The pursuit of an alternative to Portland cement, Cement and Concrete Research, 41 (2011) 7, 750-763, doi:10.1016/ j.cemconres.2011.03.016

${ }^{24}$ S. A. Bernal, D. Herfort, J. Skibsted, Hybrid binders based on sulphate-activated Portland clinker and metakaolin, In.Proceedings of XII international congress on the chemistry of cement, Madrid, Spain, 2011 (CD-Rom

${ }^{25}$ S. A. Bernal, R. Mejia de Gutierrez, J. L. Provis, Engineering and durability properties of concretes based on alkali-activated granulated blast furnace slag/metakaolin blends, Construction and Building Materials, 33 (2012), 99-108, doi:10.1016/j.conbuildmat. 2012.01.017

${ }^{26}$ S. Kumar, R. Kumar, S. P. Mehrotra, Influence of granulated blast furnace slag on the reaction, structure and properties of fly ash based geopolymer, Journal of Materials Science, 45 (2010) 3, 607-615, doi:10.1007/s10853-009-3934-5

${ }^{27}$ C. Shi, R. L. Day, Early strength development and hydration of alkali-activated blast furnace slag/fly ash blends, Advances in Cement Research, 11 (1999) 4, 189-196, doi:10.1680/adcr.1999. 11.4.189

${ }^{28}$ A. Buchwald, H. Hilbig, Ch. Kaps, Alkali-activated metakaolin-slag blends - performance and structure in dependence of their composition, Journal of Materials Science, 42 (2007) 9, 3024-3032, doi:10.1007/s10853-006-0525-6

${ }^{29} \mathrm{Z}$. Li, S. Liu, Influence of slag as additive on compressive strength of fly ash-based geopolymer, J. Mater. Civ. Eng., 19 (2007) 6, 470-474, doi:10.1061/(ASCE)0899-1561(2007)19:6(470)

${ }^{30}$ F. Puertas, A. Fernandez-Jimenez, Mineralogical and microstructural characterisation of alkali-activated fly ash/slag pastes, Cement and Conrete Composites, 25 (2003) 3, 287-292, doi:10.1016/s09589465(02)00059-8

${ }^{31} \mathrm{~T}$. Bakharev, Resistance of geopolymer materials to acid attack, Cement and Concrete Research, 35 (2005) 4, 658-670, doi:10.1016./ j.cemconres.2004.06.005

${ }^{32}$ S. Thokchom, P. Ghosh, S. Ghosh, Resistance of fly ash based geopolymer mortars in sulfuric acid, ARPN Journal of Engineering and Applied Sciences, 4 (2009) 1, 65-70

${ }^{33}$ V. Sata, A. Sathonsaowaphak, P. Chindaprasirt, Resistance of lignite bottom ash geopolymer mortar to sulfate and sulfuric acid attack, Cement and Concrete Composites, 34 (2012) 5, 700-708, doi:10.1016/j.cemconcomp.2012.01.010

${ }^{34} \mathrm{~S}$. A. Bernal, Carbonatacion de concretos producidos en sistemas binaries de unaescoria siderorgica, Ph.d. Thesis, Universidad dei valle, Cali, Colombia, 2009

${ }^{35}$ M. O. Yusuf, M. A. M. Johari, Z. A. Ahmad, M. Maslehuddin, Strength and microstructure of alkali-activated binary blended binder containing palm oil fuel ash and ground blast-furnace slag, Construction and Building Materials, 52 (2014), 504-510, doi:10.1016/j.conbuildmat.2013.11.012

${ }^{36}$ K. Kannapiran, T. Sujatha, S. Nagan, Resistance of reinforced geopolymer concrete beams to acid and chloride migration, Asian Journal of Civil Engineering, 14 (2013) 2, 225-238 